\title{
液相の粘性が鉛直管内単一大気泡周囲の平均速度場に及ぼす影響*
}

\author{
南川久人*1, 山田哲 史 ${ }^{* 2}$ \\ 安田孝宏*1, 塩見洋一*3
}

\section{Effect of Liquid Viscosity on the Average Velocity Field around Single Large Bubbles in a Vertical Pipe}

\author{
Hisato MINAGAWA*4, Satoshi YAMADA, \\ Takahiro YASUDA and Yoichi SHIOMI \\ ${ }^{* 4}$ Department of Mechanical Systems Engineering, The University of Shiga Prefecture, \\ 2500 Hassaka-cho, Hikone-shi, Shiga, 522-8533 Japan
}

\begin{abstract}
The effect of viscosity of the liquid phase on the averaged liquid velocity field in front of, around and behind the large bubble rising in stagnant liquid in a circular pipe of inner diameter $D=40.0 \mathrm{~mm}$ is measured. Ultrasonic Velocity Profile monitor (UVP) is used to measure the velocity field. The instrumentation and measurement method are similar to those the authors have presented in the previous paper ${ }^{(2)}$. Five kinds of silicone oil whose kinetic viscosities cover $102 \sim 8946 \mathrm{~mm}^{2} / \mathrm{s}$ and water are used as the liquid phase. In the liquid phase in front of the large bubble, the magnitude of small upward velocities decreases with increasing the kinetic viscosity. In the liquid film around the large bubble, the downward acceleration is small when compared with water. The maximum downward velocity in the film soon becomes a constant value of bubble rising velocity approximately if the kinetic viscosities are larger than $330 \mathrm{~mm}^{2} / \mathrm{s}$. In the wake behind the bubble tail, a large ring vortex, which appeared when water is used, is not recognized for the silicone oil.
\end{abstract}

Key Words : Large Bubble, Multiphase Flow, Average Velocity Field, Viscosity, Wake, Velocity Profile, UVP

\section{1. 緒論}

鉛直管内気液二相スラグ流は, 種々の工業配管系, 化学工学装置・発電所や流体機器内で頻繁に出現する ものの ${ }^{(1)}$, その微視的特性は十分解明されているとは いえない。これは, 大気泡の先端から周囲の液膜一流 れが落下し, 液体スラグ部上部のウェイク部で渦を引 き起こすといった複雑な流れの構造, あるいは気泡分 布などが系統的に把握されていないのが一因である. このようなデータを系統的に取得するために，著者ら は鉛直管内気液二相スラグ流の単純型と考えられる， 静止水中を上昇する単一大気泡を取り上げ，その周囲 の平均速度場を超音波流速分布計(Ultrasonic Velocity Profile monitor : UVP)を用いて明らかにする方法を提 示した ${ }^{(2)}$.これは，管内径 $54 \mathrm{~mm}$ の鉛直円管の中心軸 を含む面内に 2 方向（水平に対して $\pm 20^{\circ}$ ) に向けた 2 本の超音波トランスデューサを配置し，管内に水を 満たしたのち, そこに単一大気泡を複数回上昇させて,

* 原稿受付 2007 年 7 月 23 日.

*1 正員, 滋賀県立大学工学部(画522-8533 彦根市八坂町 2500).

*2 正員, マツイ機器工業(株) (志526-0802 長浜市東上坂町 242-5).

${ }^{* 3}$ 正員, 龍谷大学理工学部(画520-2194 大津市瀬田大江町横 谷 1-5)

E-mail : minagawa@ mech.usp.ac.jp
その速度分布を測定し, 平均值を表示したものである. その結果, 大気泡上部の液相中から周囲の液膜内, さ らには大気泡後方のウェイク部での速度場の特徴が明 らかになった。たとえば，大気泡上部の液相中では， 大気泡の直上に上向きの流れができ, これが中心から 管壁方向に大きく傾き, やがて大気泡界面に沿う流れ となり周囲の液膜へと落ちていく．この流れと大気泡 先端付近から管壁近くでできる鉛直下向きの壁に沿う 流れが, やがて合流し, 複雑な速度分布を形成する. 大気泡周囲の液膜内速度場での落下最大速度は, 最初 から自由落下曲線に沿うことなく, 重力加速度より小 さな加速度で増速している，さらに，大気泡後方のウ エイク部で管壁付近では，管壁付近の強い下向きの流 れと管軸付近での上に向かう流れが起因する環状の渦 が, 大気泡後端付近に生じていることなどが確認され $た^{(2)}$.

ところで, このような単一大気泡周囲の平均速度場 に，液相の粘性が及ぼす影響に関する知見は，現在ま であまり得られていない. Nogueira ら ${ }^{(3)}$ は, 水性グリ セリン溶液を用いて, 粘度が $2 \sim 178 \mathrm{mPa} \cdot \mathrm{s}$ の範囲で PIV によりウェイク部のみの速度場を測定し, 粘性に 
よって 3 種類の流動様式になることを確認している. Bugg $ら^{(4)}$ は, 動粘度約 $92 \mathrm{~mm}^{2} / \mathrm{s}$ のオリーブオイルを 用いて PIV による大気泡先端部とウェイク部の速度場 を計測した。非常に精度の高い測定結果であるが，流 動条件が限られ，系統的なデー夕は得られていない， そこで，本研究では，基本的に既報 ${ }^{(2)} と$ 同じUVPによ る測定法を適用し, 水に加えて, 動粘度の異なる 5 種 類のシリコンオイルを液相として用い，管内径 $40.0 \mathrm{~mm}$ の鉛直円管中を上昇する単一大気泡の周囲の 平均速度場を測定した結果について, 報告する。

\section{2.おもな 記 号}

$D ：$ 管内径 $(\mathrm{m})$

$L_{0}$ ： 初期気泡長さ $(\mathrm{m})$

$r$ : 管中心軸からの半径方向距䧹 $(\mathrm{m})$

$u$ : 局所速度 $(\mathrm{m} / \mathrm{s})$

$u_{\mathrm{B}}$ ：大気泡の終端上昇速度 $(\mathrm{m} / \mathrm{s})$

$Z$ ：大気泡後端から下方への距離 $(\mathrm{m})$

$z:$ 大気泡先端から下方への距離 $(\mathrm{m})$

$v$ : 動粘度 $\left(\mathrm{mm}^{2} / \mathrm{s}\right)$

\section{3. 実験装置及び方法}

3.1 実験装置と方法既報(2)でも述べたように, UVP は，トランスデューサからパルス状の超音波ビー ムを発信し, 液中にある微細粒子から反射してきたエ コーを同じトランスデューサで受信し，ドップラー周 波数を求める。計測線上の速度分布は, パルス発信か ら受信までの時間差より位置を算出し, 瞬時のドップ ラ一周波数より微細粒子速度を算出することで求めら れる. 一平面上に異なった方向に向けた 2 本のトラン スデューサを配置すれば, 各計測線方向の速度成分が わかるので, これより実際の速度べクトルが算出でき る.ただし，このままでは大気泡のどの部分からのエ コーであるのかが特定できないので，液相が水の場合 には，管中心付近に導電部をもつ電極を設置し，その 信号を利用した。一方, 液相がシリコンオイルではこ れが使えないため, 今回はエコーの信号をよく調べ, 大気泡先端が到達した際に生じる管中心付近の信号の 特徵的な波形を抽出し，そこを先端位置とした。この 位置は，別途ビデオ撮影画像と照合した結果，妥当で あることが確認できた。

液相としてシリコンオイルを用いる場合の実験装置 の全体図を図 1 に示す。なお，液相として水道水を用 いたときの実験装置ならびに方法は，既報(2)のものと 管内径を除いて同じであるので，ここでは省略する.
まず，図１の管内にシリコンオイルを満たす。この 際，下部にある 2 つのボールバルブのうち，下側のボ ールバルブ 1 のみを閉めておく.シリコンオイル中に は, 超音波の反射体として低密度ポリエチレン粒子(中 位粒子径 $160 \mu \mathrm{m}$, 平均質量濃度 $0.0375 \%$ )を混入させ た。この粒子は微細で, シリコンオイルの密度（968 $\left.\sim 974 \mathrm{~kg} / \mathrm{m}^{3}\right)$ と比較的近い密度 $\left(918 \mathrm{~kg} / \mathrm{m}^{3}\right)$ をもつた め, 管内であまり浮上をせず，ほぼ一定の位置にとど まっている。

次に, 上側のボールバルブ 2 も閉め, 空気入口弁と オイル排出弁の両方を開き，空気を一定量，注入する. 図では省略しているが，実際のオイル排出弁は 4 個付 けており，その位置により初期気泡長さ $L_{0}$ （オイル排 出弁からボールバルブ 2 の下面部までの距離）が決定 される. その後, ボールバルブ 2 を開くことによって, 空気は大気泡となって, シリコンオイルで充たされた 管内を上昇し, 約 $1500 \mathrm{~mm}$ 上方の試験部で, 治具に取 り付けたUVPトランスデューサの前を通過する。

試験部には, 図 1 の左側のように UVP のトランス デューサ（周波数 $4 \mathrm{MHz}$ ，ビーム径 $5 \mathrm{~mm}$ ）を水平に

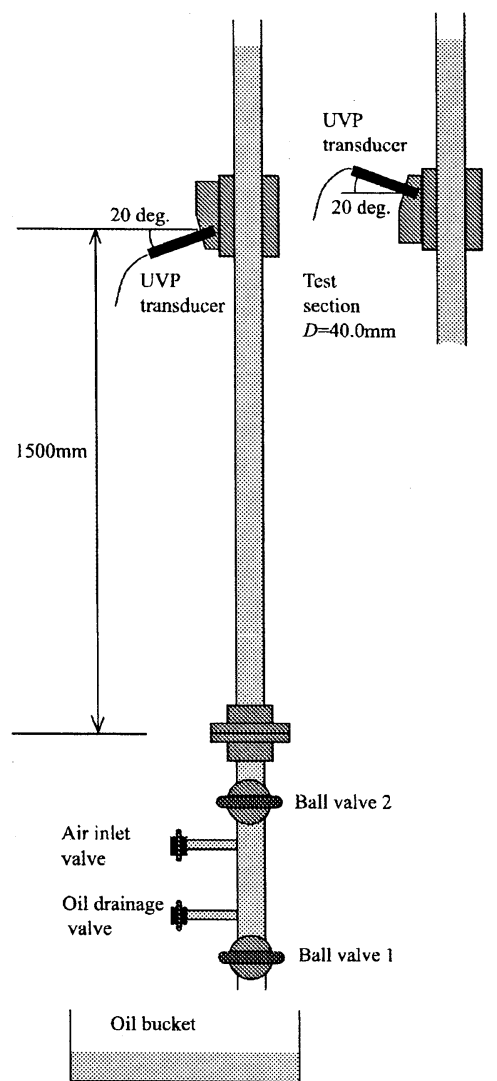

Fig.1 Experimental Apparatus 


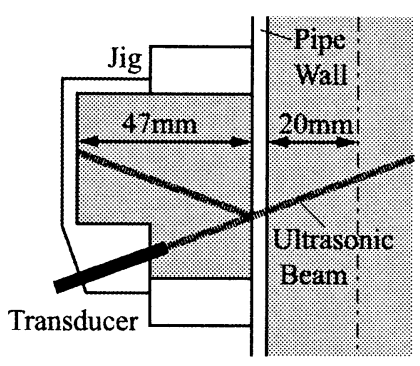

Fig.2 Setting of a UVP Transducer

対して上向き $20^{\circ}$ で設置した場合と，右側のように下 向き $20^{\circ}$ で設置した両方の角度で, 各流動条件に対し て測定を行った。

図 2 に測定部のトランスデューサ取り付け治具の詳 細を示す.この図は, トランスデューサを水平に対し て上向き $20^{\circ}$ で設置した場合である. トランスデュー サは，管軸を含む面内に取り付けた。超音波の減衰を 防ぐため, トランスデューサ先端は，管内と同じシリ コンオイルを満たした部分に入れた。図のように, ト ランスデューサから発信された超音波は管壁面で反射 し，トランスデューサ治具の壁に当たる. 予備検討に おいて，この治具から返ってきた信号をトランスデュ 一サが受信してしまい, 流れ場から返ってきた信号と 平均化され, 速度值が極端に小さくなることがわかっ た.この問題を解消するために, 治具の壁から返って きた信号が管中心軸より遠方のデータとなるように， 管壁と治具の壁の間に十分な距離 $(47 \mathrm{~mm})$ を設けた.

測定は, 水と 5 種類の動粘度の異なるシリコンオイ ルの計 6 種類の液相に対し, 大気泡長さが異なる 4 種 類のグループの計 24 条件に対して実施し, 各方向の トランスデューサにつき, 各条件最低 20 個の大気泡 についての速度データを取得した，なお，既報(2)でも 述べたように, 本測定法では管路を流動軸方向に $5.38 \mathrm{~mm}$ 刻み, 半径方向に $0.695 \mathrm{~mm}$ 刻みのセルに分割 し, 各セル内に含まれる方向ごとの速度データを算術 平均し, さらに 2 方向の算術平均值から各セル中心に おける速度ベクトルを算出する. 超音波ビーム径が $5 \mathrm{~mm}$ で, $20^{\circ}$ 傾けて測定することによって測定体積 の周辺部の 51\%が両側のセルに重なってしまうという 欠点があり, これにより速度勾配が急峻な液膜部など では測定誤差が大きくなると考えられる，したがって， このような部分での速度勾配の検討は本研究では行わ ない，また，大気泡周囲の速度場測定においては，管 中心より手前半分のみを測定した. 管全体のイメージ を表示する際には，管軸対称の仮定の下，反対側には それを折り返したデータを表示することとする.
3.2 測定に用いたシリコンオイル＼cjkstart液相として， 水のほかに, 比較的水と近い密度をもち, 無色透明な 5 種類のシリコンオイル (品名: TSF451 シリーズ, GE 東芝シリコーン株式会社製）を用いた。 その諸特 性を表 1 に示す. シリコンオイルの動粘度は, ウベロ 一ゼ粘度計を用いて測定した結果である。液温を $20 \pm 1{ }^{\circ} \mathrm{C}$ に調節し，それぞれ 5 回ずつの測定から得られ た平均値を動粘度として用いた。水 $\left(20^{\circ} \mathrm{C}\right)$ の動粘度 がほぼ $1 \mathrm{~mm}^{2} / \mathrm{s}$ であるので, 各シリコンオイルの動粘 度の值は, 水のほぼ 100〜9000 倍ということになる.

音速測定には, 超音波探傷計を用いた。 $5 \mathrm{MHz}$ の超音 波パルスを入射してから 1 回反射の底面エコー, 2 回 反射の底面エコーが到達するまでの時間差を測定し，

音速を求めた。 密度, 表面張力, 屈折率はメーカーに よるカタログ值である。

Table 1 Properties of Silicone Oils under Test

\begin{tabular}{|c|c|c|c|c|c|}
\hline Product & $\begin{array}{c}\text { Density } \\
{\left[\mathrm{kg} / \mathrm{m}^{3}\right]}\end{array}$ & $\begin{array}{c}\text { Kinetic } \\
\text { Viscosity } \\
{\left[\mathrm{mm}^{2} / \mathrm{s}\right]}\end{array}$ & $\begin{array}{c}\text { Surface } \\
\text { Tension } \\
{[\mathrm{mN} / \mathrm{m}]}\end{array}$ & $\begin{array}{c}\text { Refractive } \\
\text { Index } \\
{[-]}\end{array}$ & $\begin{array}{c}\text { Sound } \\
\text { Velocity } \\
{[\mathrm{m} / \mathrm{s}]}\end{array}$ \\
\hline $\begin{array}{c}\text { TSF451- } \\
100\end{array}$ & 968 & 102 & 20.8 & 1.401 & 1014 \\
\hline $\begin{array}{c}\text { TSF451- } \\
350\end{array}$ & 970 & 330 & 20.9 & 1.403 & 1014 \\
\hline $\begin{array}{c}\text { TSF451- } \\
1000\end{array}$ & 971 & 951 & 21.1 & 1.404 & 1015 \\
\hline $\begin{array}{c}\text { TSF451- } \\
3000\end{array}$ & 972 & 2937 & 21.2 & 1.404 & 1025 \\
\hline $\begin{array}{c}\text { TSF451- } \\
1 \mathrm{M}\end{array}$ & 974 & 8946 & 21.4 & 1.404 & 1011 \\
\hline
\end{tabular}

3.3 大気泡形状の測定 予備実験として, 大気泡の 形状を測定した. 光の屈折の影響による画像の変形を 小さくするため, 試験部のみを外形断面が正方形の管 に替えてディジタル・ビデオにより正面から大気泡を 撮影した。なお，内側は，速度分布測定時と同じ，内 径 40.0 mm の円形である。 その結果を図 3 に示す。動 粘度が大きくなるに従い, 気泡形状が砲弾形から楕円 球形一と変化していくことがわかる. シリコンオイル 中を上昇する気泡は，気泡後端における小気泡の離脱 が水に比べて非常に少なく，もつとも動粘度が小さい $v=102 \mathrm{~mm}^{2} / \mathrm{s}$ の場合でも，数個の小気泡が見えている だけである. その $v=102 \mathrm{~mm}^{2} / \mathrm{s}$ の気泡後端は, 気泡内 部に大きな空隙がある，いわゆるスカート状になって おり上昇に伴って摇らいでいた. $v=330 \mathrm{~mm}^{2} / \mathrm{s}$ となる と，スカート部が少し短くなり，形状も摇らぐことな く安定している. $v=951 \mathrm{~mm}^{2} / \mathrm{s}$ 以上の高い動粘度のシ リコンオイルでは，スカート部はほぼ確認できなくな り, 気泡の先端・後端が同じ形状の楕円球形となる. 
それ以降動粘度を増やしても形状に大きな変化は見ら れないが液膜が除々に厚くなっているようである。ま た，水で見られたような，大気泡後端に向かって液膜 が薄くなっていく傾向もv $=102 \mathrm{~mm}^{2} / \mathrm{s}$ 以外は見られず， 先端から少し離れたところで, 液膜厚さは一定となっ ているようである.

そこで, 液膜が一定となったときの液膜厚さを測定
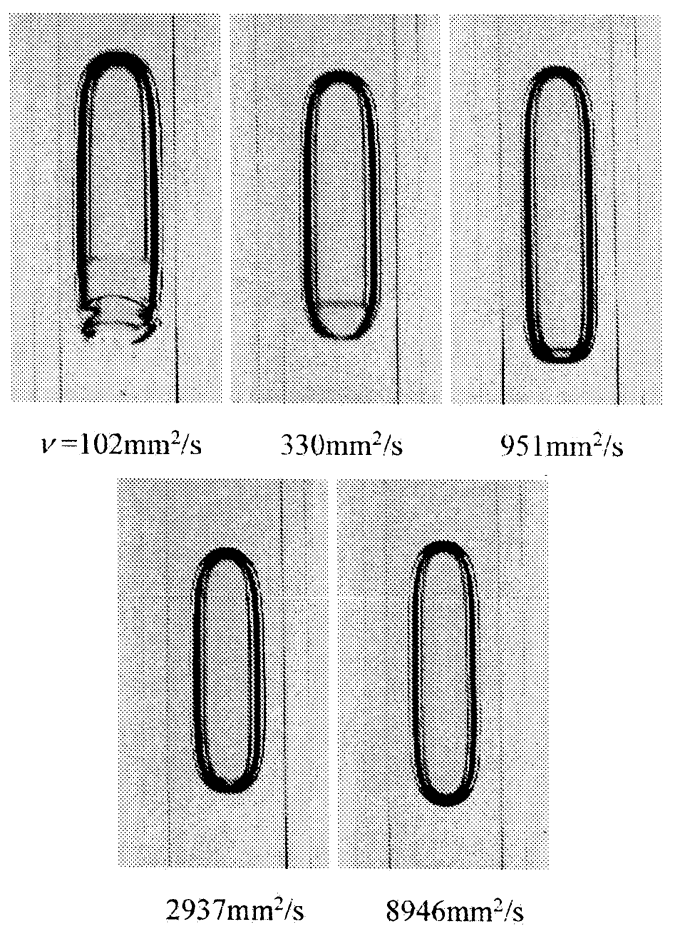

Fig. 3 Shapes of Single Large Bubbles Rising in Silicone Oil

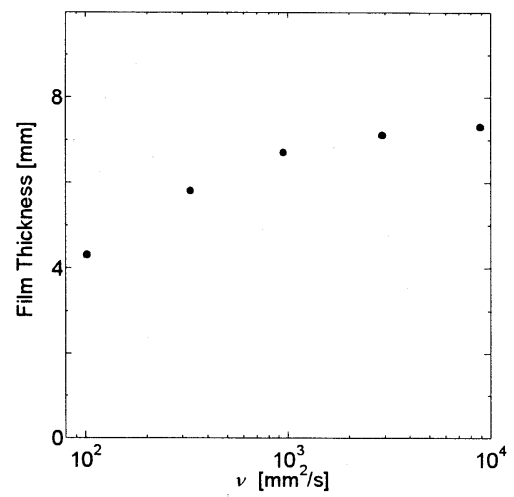

Fig.4 Film Thickness
し，その結果を図4 に示す. 図 3 の画像は前述の通り 外形断面が正方形の管を用いて撮影したが，それでも わずかに屈折の影響は残るので，これを考虑して気泡 外形を算出した. 動粘度の増加に伴い, 液膜が厚くな っていることが確認できるが，その増加の割合は次第 に小さくなっている.

3.4 大気泡の上昇速度 大気泡の終端上昇速度に ついても，あらかじめ検討した，形状同様，ビデオ画 像を用いて測定した大気泡終端上昇速度を表 2 に示す. White $ら^{(5)}$ は, 大気泡上昇速度をボンド数とモルトン 数ならびにフルード数の線図にまとめ, これよりさま ざまな管内径の鉛直管内においてさまざまな物性をも つ液相中の大気泡終端上昇速度を推定可能となってい る. 表 2 の結果と, White らの線図から読み取った結 果を比較すると, 平均 $\pm 3.1 \%$ で一致した。

Table 2 Terminal Rising Velocity of

Single Large Bubbles in Silicone Oil

\begin{tabular}{|c|c|c|c|c|c|c|}
\hline $\begin{array}{c}\text { Kinetic } \\
\text { Viscosity }\end{array}$ & {$\left[\mathrm{mm}^{2} / \mathrm{s}\right]$} & 102 & 330 & 951 & 2937 & 8946 \\
\hline $\begin{array}{c}\text { Large Bubble } \\
\text { Rising Velocity }\end{array}$ & {$[\mathrm{mm} / \mathrm{s}]$} & 208 & 189 & 114 & 51.3 & 17.2 \\
\hline
\end{tabular}

\section{4. 実験 結果及び考察}

4.1 速度場の概要 図 5 は大気泡周囲液相内の 速度場全体像をべクトルで示した代表例として，スカ 一ト状の部分がある(a) $v=102 \mathrm{~mm}^{2} / \mathrm{s}$ とそれのない(b) $v$ $=2937 \mathrm{~mm}^{2} / \mathrm{s}$ のものである. ともに初期気泡長さ $L_{0}=$ $2.0 D$ に対しての結果である.ここで $D$ は管内径，また 図中の $Z$ は大気泡後端, $z$ は先端を基準として管路下 向きを正とする座標である.(a)の $Z=0$ に示す破線は実 際の大気泡後端が確認された位置で, それ以降はスカ 一ト状の部分である. 全般的に見ると，大気泡先端の 上部には大気泡の上昇により押し上げられたようなわ ずかな上向きの速度が測定されている。これは Bugg $ら^{(4)}$ の結果と一致する。大気泡周囲の液膜内には，下 向きに流れがあるが，先端部近くを除いて，水の場合 のように顕著な下向きの加速は見られない，液膜下部 や大気泡後端の下部にあるウェイク部においても，水 の場合 ${ }^{(2)} に$ 見られたような大きな速度や，顕著な渦の 構造は見られない. (a)と(b)での速度の大きさの違いは 一見顕著ではないが, これはべクトルの単位長さあた りの速度の大きさが $(\mathrm{a})$ と(b)では異なるためで, 実際 の速度ベクトルの絶対值は, 動粘度の大きい(b)より, 


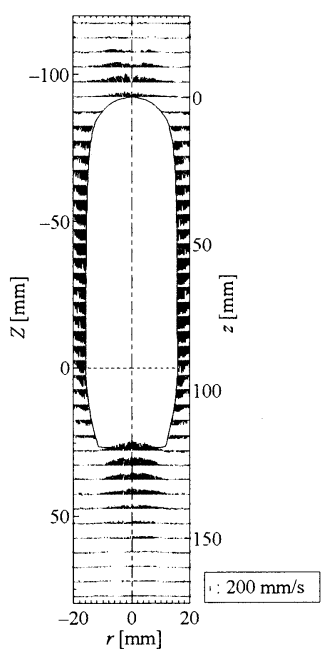

(a)

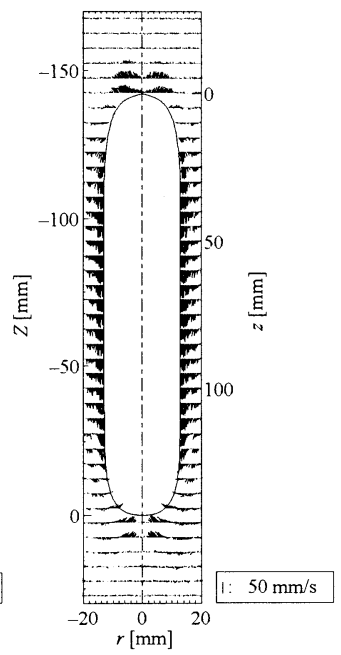

(b) $v=102 \mathrm{~mm}^{2} / \mathrm{s}$ $v=2937 \mathrm{~mm}^{2} / \mathrm{s}$

Fig. 5 Velocity Fields for $L_{0}=2.0 \mathrm{D}$

小さい(a)の方が，ずいぶんと大きいことが確認できる. また，スカート状部の有無による違いはあまり顕著で はなく，スカート状部のある(a)ではあたかもスカート 後端が(b)の大気泡後端のようにふるまい,この下側に 大気泡を追う上向きの流れが見られる。

速度場に及ぼす，動粘度による影響をさらに詳し く見るために, 水の結果ならびに図 5 の 2 条件を含 めた初期気泡長さ $L_{0}=1.5 D$ におけるすべての動粘度で の速度場の測定結果を, 図6に示す.ただし, 紙面 の都合で，管全体でなく，左半分のみを表示した。

ここでも，単位ベクトルの速度の大きさが各動粘度毎 に異なることに注意されたい. 左端に水での結果, そ れより右はシリコンオイルの結果で, 右に行くほど動 粘度の大きいものである. 測定された速度の大きさは, 全般的に水で最大, 以降, 動粘度が増すほど小さくな っている. 大気泡先端部の上向き流れはいずれの場合 も見られるが, その速度の大きさは, やはり動粘度が 増すほど小さくなっている. また, 水では後端に達し た液膜流が，そのまま壁際を流下する流れを形成し， その影響で管中心部には大気泡を追う上向き流れが発 達し，これらが大きな渦を作っている(2).これに対し， 動粘度の大きいシリコンオイルの場合, スカート状の 部分を含めた後端部は, 徐々に気泡が細みを帯びる形 状なので, 液膜流はそれに伴って広がり, 流下速度は 低下している，したがって，水の場合のような壁際の 下向き流れは，ほとんど見られない，一方，管中心部 には大気泡を追う上向き流れが見られるものの，その

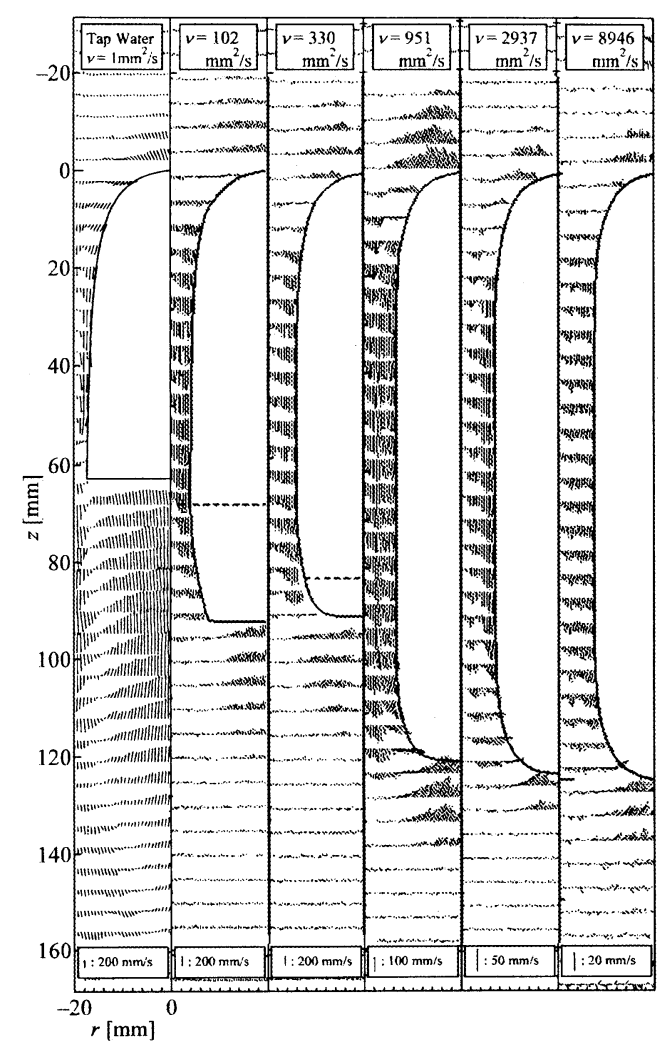

Fig.6 Effect of Viscosity on Velocity Fields for $L_{0}=1.5 \mathrm{D}$

領域は大気泡, あるいはスカート状の部分の後端から わずかに下にいくと消えてしまい，水の場合のような 渦は見られない。

4.2 大気泡周囲の液膜 液膜内速度ベクトルの, 鉛 直下向きの速度成分のうちの最大值 $u_{\mathrm{z} \max }$ を大気泡上昇 速度 $u \mathrm{~B}$ で除して, $z$ に対してプロットしたのが図 7 で ある. 記号 ○で示す水の場合, $z=0$ から初速度 0 で自由 落下する曲線よりは少し小さい速度で落下し, 本実験の 最長の大気泡長さ $\left(L_{0}=4.0 D\right)$ においても, 後端まで加 速を続けていた(2). しかし, 動粘度の大きいシリコン オイルの場合は, 異なる特性を示した. シリコンオイ ルのうちでは最も動粘度の小さい $v=102 \mathrm{~mm}^{2} / \mathrm{s}$ の場合 （記号匹），先端から $30 \mathrm{~mm}$ 程度は，気泡と管壁の間 隙の形状変化に対応して見かけ上, 加速しているもの の, その後急激に加速度を減少させ, $u_{\mathrm{zmax}} / u_{\mathrm{B}}=2$ 程度 の一定值となっている. それ以上の動粘度をもつシリコ ンオイルの場合, やはり先端から $30 \mathrm{~mm}$ 程度は加速し ているものの, その程度は小さく， $u_{\mathrm{z} \max } / u_{\mathrm{B}}=1$ 程度の 值となると加速を止め, 一定速度で下降していく.すな 


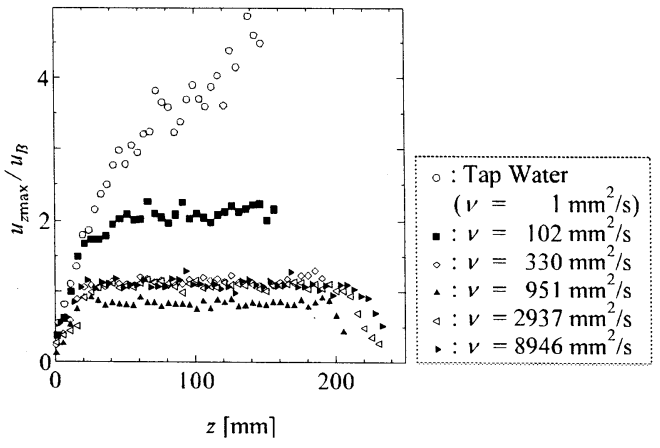

Fig. 7 Maximum Downward Velocities in the Liquid Film for $L_{0}=4.0 \mathrm{D}$

わち, 最大液膜下降速度は, ほぼ大気泡上昇速度と等し いということになる. 図で $z=200 \mathrm{~mm}$ あたりから再び減 速するのは，前節で述べたとおり，大気泡形状が後端で 丸まり, 液膜が厚くなるために見かけ上, 減速している ためである。

4.3 大気泡後方のウェイク部図 8 に大気泡後端 からの距離 $Z$ ごとに, 速度べクトルの鉛直上向きの速 度成分一 $u_{\mathrm{z}}$ を, 大気泡上昇速度 $u_{\mathrm{B}}$ で除したものを縦軸 に, 半径方向位置を横軸にとって示す. 4.1 節で述べた ように，記号 ○で示す水の場合，管壁近くに下向きの， 管軸周辺に上向きの大きな速度をもつ. 後者の上向き速 度は, 大気泡後端直後より, 少し離れたところで最大值 をもつ ${ }^{(2)}$. シリコンオイルのうち, 最も動粘度の小さ い $v=102 \mathrm{~mm}^{2} / \mathrm{s}$ の場合（記号四），大気泡直後は，ス カート状部分の影響で測定できず， $Z=32.5 \mathrm{~mm}$ で，は じめてデータが現れているが，ここでは水と同様に管 軸周辺に上向きの速度をもつ. しかし，その絶対値はず いぶんと小さい，それ以上の動粘度の場合は， $Z=2.5 \mathrm{~mm}$ 〜22.5mm では，多少の上向き流れが見られるが，大 気泡から離れるとともに急激に減衰し，それ以降，ほ ぼ静止している.

\section{5. 結 論}

本研究では，基本的に既報 ${ }^{(2)}$ と同じ UVPによる測定 法を適用し，水に加えて，動粘度 $v=102 \sim 8946$ $\mathrm{mm}^{2} / \mathrm{s}$ の 5 種類のシリコンオイルを液相として用い, 管内径 $40.0 \mathrm{~mm}$ の鉛直円管中を上昇する単一大気泡の 周囲の平均速度場を測定し, 液相粘性の変化が, 速度 場に及ぼす影響を検討した。 その結果，以下の知見を 得た。

（1）シリコンオイルを用いた場合でも，水と同様に 大気泡先端の上部にわずかな上向きの速度が測定され

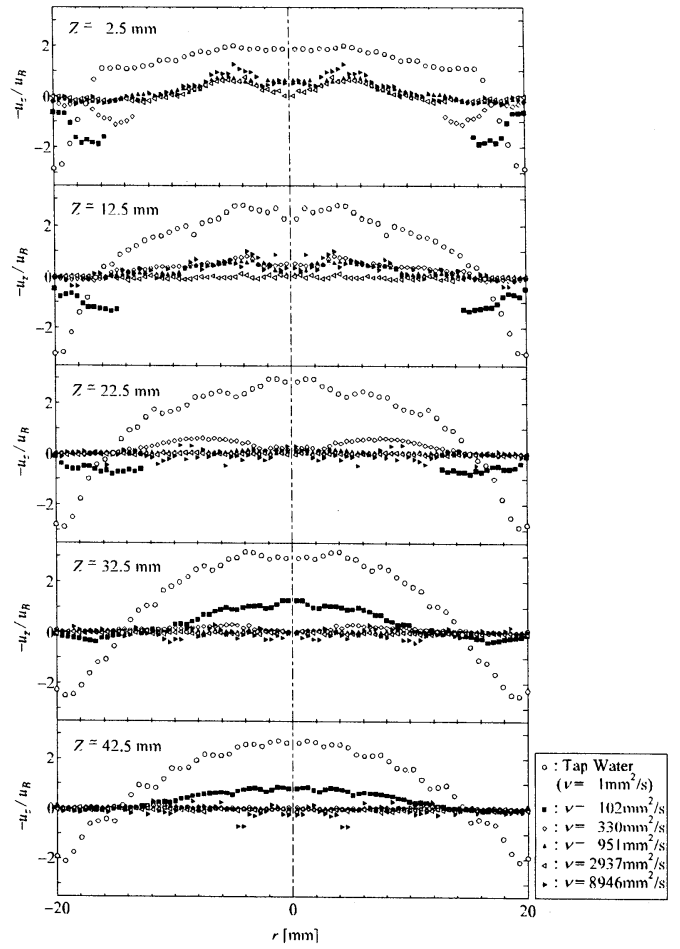

Fig. 8 Velocity Profiles in the Wake behind the Large Bubble

たが，その速度の大きさは，動粘度が増すほど小さく なった。

（2）大気泡周囲の液膜内には，下向きの流れがある が, 先端部近くを除いて, 水の場合のように顕著な下 向きの加速は見られなかった。 $v=330 \mathrm{~mm}^{2} / \mathrm{s}$ 以上の動 粘度をもつシリコンオイルの場合, 先端から $30 \mathrm{~mm}$ 程度 は，気泡と管壁の間隙の形状変化に対応して見かけ上， 加速しているものの, その加速度は小さく, $u_{\mathrm{z} \max } / u_{\mathrm{B}}=$ 1 程度の值となると加速を止め, 一定速度で下降した。 これは, 最大液膜下降速度は, ほぼ大気泡上昇速度と等 しいということを意味する．また，後端に向かうにつれ， 徐々に気泡が細みを帯びる形状のため, 液膜流はそれ に伴って拡がり，下降速度は再び低下した。

（3）シリコンオイルを用いた場合，大気泡後端の下 部においても，大きな速度や，顕著な渦の構造は見ら れなかった，速度の減衰の度合いは非常に大きく， $v=$ $330 \mathrm{~mm}^{2} / \mathrm{s}$ 以上の動粘度をもつシリコンオイルの場合, 後端から $30 \mathrm{~mm}$ 以上離れると, ほぼ静止した。

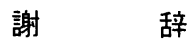

実験遂行にご協力いただいた元滋賀県立大学大学院 
工学研究科学生の中澤喜之氏, 元工学部学生の美馬興 己氏に感謝する.

\section{文献}

(1) The Japan Society of Mechanical Engineers ed., Handbook of Gas-Liquid Two-Phase Flow Technology, Corona Publishing, Tokyo(1989).

(2) Minagawa, H., Fukazawa, T., Nakazawa, Y., Yamada, S. and Shiomi, Y., Measurement of Averaged Liquid Velocity Field around Large Bubbles Using UVP, Transactions of the Japan Society of Mechanical Engineers, Series B, Vol.72, No.714(2006), pp.345-352.
(3) Nogueira, S., Riethmuller, M., Campos, J.B.L.M. and Pinto, A.M.F.R., Flow Patterns in the Wake of Taylor Bubbles Rising in Stagnant Liquid, Proceedings of the 4th International Conference on Multiphase Flow, New Orleans, (2001), Paper No.899, in CD-Rom.

(4) Bugg, J.D. and Saad, G.A., The Velocity Field around a Taylor Bubble Rising in a Stagnant Viscous Fluid: Numerical and Experimental Results, International Journal of Multiphase Flow, Vol.28(2002), pp.791-803.

(5) White, E.T. and Beadmore, R.H., The Velocity of Rise of Single Cylindrical Air Bubbles through Liquids Contained in Vertical Tubes, Chemical Engineering Science, Vol.17(1962), pp.351-361. 